\title{
Correction to: Developing a Framework for Public Involvement in Mathematical and Economic Modelling: Bringing New Dynamism to Vaccination Policy Recommendations
}

\author{
Sophie Staniszewska ${ }^{1}$ - Edward M. Hill ${ }^{2}$. Richard Grant ${ }^{3}$. Peter Grove ${ }^{4}$ Jarina Porter ${ }^{3}$. Tinevimbo Shiri ${ }^{5}$. \\ Sue Tulip ${ }^{3} \cdot$ Jane Whitehurst ${ }^{3} \cdot$ Claire Wright $^{6} \cdot$ Samik Datta $^{7} \cdot$ Stavros Petrou $^{8,9} \cdot$ Matt Keeling $^{2}$
}

Published online: 12 February 2021

(c) The Author(s) 2021

\section{Correction to: \\ The Patient - Patient-Centered Outcomes Research https://doi.org/10.1007/s40271-020-00476-x}

The article "Developing a Framework for Public Involvement in Mathematical and Economic Modelling: Bringing New Dynamism to Vaccination Policy Recommendations", written by Sophie Staniszewska, Edward M. Hill, Richard Grant, Peter Grove, Jarina Porter, Tinevimbo Shiri, Sue Tulip3, Jane Whitehurst, Claire Wright, Samik Datta, Stavros Petrou, Matt Keeling was originally published electronically on the publisher's internet portal on 21 October 2020 without open access.

With the author(s)' decision to opt for Open Choice the copyright of the article changed on 28 January 2021 to (C) The Author(s) 2021 and the article is forthwith distributed under a Creative Commons Attribution-Noncommercial 4.0 International License, which permits any non-commercial use, sharing, adaptation, distribution and reproduction in any medium or format, as long as you give appropriate credit to the original author(s) and the source, provide a link to the Creative Commons license, and indicate if changes were made. The images or other third party material in this article are included in the article's Creative Commons license, unless indicated otherwise in a credit line to the material. If material is not included in the article's Creative Commons license and your intended use is not permitted by statutory regulation or exceeds the permitted use, you will need to obtain permission directly from the copyright holder. To view a copy of this license, visit http://creativecommons.org/licenses/by-nc/4.0/.

The original article has been corrected.

Open Access This article is licensed under a Creative Commons Attribution-Noncommercial 4.0 International License, which permits any non-commercial use, sharing, adaptation, distribution and reproduction in any medium or format, as long as you give appropriate credit to the original author(s) and the source, provide a link to the Creative Commons license, and indicate if changes were made. The images or other third party material in this article are included in the article's Creative Commons license, unless indicated otherwise in a credit line to the material. If material is not included in the article's Creative Commons license and your intended use is not permitted by statutory regulation or exceeds the permitted use, you will need to obtain permission directly from the copyright holder. To view a copy of this license, visit http:// creativecommons.org/licenses/by-nc/4.0/.

The original article can be found online at https://doi.org/10.1007/ s40271-020-00476-x.

Sophie Staniszewska

Sophie.Staniszewska@warwick.ac.uk

1 Division of Health Sciences, Warwick Medical School, University of Warwick, Coventry CV4 7AL, UK

2 The Zeeman Institute for Systems Biology and Infectious Disease Epidemiology Research, School of Life Sciences and Mathematics Institute, University of Warwick, Coventry CV4 7AL, UK

3 Warwick Medical School, University of Warwick, Coventry CV4 7AL, UK

4 Department of Health, London, UK
5 Liverpool School of Tropical Medicine, Liverpool L3 5QA, UK

6 Meningitis Research Foundation, Bristol BS1 1LT, UK

7 Population Modelling, National Institute of Water and Atmospheric Research Ltd (NIWA), Wellington, New Zealand

8 Nuffield Department of Primary Care Health Sciences, University of Oxford, Oxford OX2 6GG, UK

9 Warwick Clinical Trials Unit, Warwick Medical School, University of Warwick, Coventry CV4 7AL, UK 